\title{
Empathy, Mirror Neurons and the Subversion of Certitude: Political Writing and Creative Reading in Short-Stories by Bernard MacLaverty, William Trevor and Colum McCann
}

\author{
Claire Majola-Leblond
}

\section{(2) OpenEdition \\ Journals}

\section{Electronic version}

URL: http://journals.openedition.org/etudesirlandaises/4614

DOI: 10.4000/etudesirlandaises.4614

ISSN: 2259-8863

\section{Publisher}

Presses universitaires de Rennes

\section{Printed version}

Date of publication: 30 June 2015

Number of pages: $305-324$

ISBN: $978-2-7535-4082-8$

ISSN: 0183-973X

\section{Electronic reference}

Claire Majola-Leblond, «Empathy, Mirror Neurons and the Subversion of Certitude: Political Writing and Creative Reading in Short-Stories by Bernard MacLaverty, William Trevor and Colum McCann », Études irlandaises [Online], 40-1 | 2015, Online since 30 June 2017, connection on 01 May 2019. URL : http://journals.openedition.org/etudesirlandaises/4614; DOI : 10.4000/etudesirlandaises.4614 


\title{
Empathy, Mirror Neurons and the Subversion of Certitude: Political Writing and Creative Reading in Short-Stories by Bernard MacLaverty, William Trevor and Colum McCann
}

\author{
Claire Majola-Leblond \\ Université Jean-Moulin Lyon 3
}

\begin{abstract}
This paper aims at bringing together literary discourse analysis and neurosciences to consider the impact the discovery of mirror-neurons might have on our understanding of empathy phenomena and consequently on the power of literature to subvert certitude. Examining shortstories set against the backdrop of The Troubles by William Trevor, Bernard MacLaverty or Colum McCann, we shall see how writers make readers literally experience in their bodies and minds conflicting perspectives, hopefully leaving them no other choice but to discard preconceived ideas. In this perspective, any act of writing becomes a political act. Paul Brennan's academic works have always seemed to me tireless efforts to develop the understanding of the other. This is offered in resonance with his deep power of empathy.

Keywords: Bernard MacLaverty, William Trevor, Colum McCann, literature - short stories, littérature - literary codes

\section{Résumé}

La présente étude vise à faire dialoguer analyse du discours littéraire et neurosciences afin de mesurer l'impact de la découverte des neurones miroirs sur notre appréhension du phénomène d'empathie en littérature. Une lecture attentive de quelques nouvelles de William Trevor, Bernard MacLaverty et Colum McCann nous permettra de comprendre comment ces écrivains obligent leurs lecteurs à remettre en question tout a priori idéologique, sur la situation nord irlandaise en particulier, en inscrivant l'expérience de l'autre dans leur chair. Tout acte d'écriture devient ainsi acte politique. L'ensemble de l'ouvre de Paul Brennan se caractérise par cet infatigable mouvement vers l'autre. Cette étude se veut hommage à son infinie capacité d'empathie.

Mots clés : Bernard MacLaverty, William Trevor, Colum McCann, littérature - nouvelles, littérature - codes littéraires
\end{abstract}

Paul's writings, as they appeared in the In Memoriam volume published in 2004 in Etudes Irlandaises can be seen as untiring quests to understand the other, moved by "intellectual curiosity and openness", displaying a profound sense of

1. Following the words of the CFP for the In Memoriam Paul Brennan Conference in Caen in 2013. 
empathy and a striking capacity to analyze questions from different angles in the cultural and political fields. In the literary domain, among the most intriguing questions are those of perspective; how readers are constantly led to share points of view that are different from their own. In the specific context of Irish Studies, the issue of differing and possibly conflicting perspectives acquires unequalled urgency. The idea therefore took shape to explore the no man's land between fiction and reality, to see how fiction, and particularly short fiction, might be a privileged path towards the understanding of otherness and lead to the indispensable subversion of all-too-often destructive allegiance. Anne Enright, editor of The Granta Book of Irish Short Story insists on the "either/or question asked by the work of contemporary writers". Cunningly adding, "is choice a particularly Irish problem 2 ?", she defines short stories, as "the cats of literary forms", enigmatic and demanding in terms of interpretation. Epiphany, one of the defining elements of the genre is often problematic and unexpected, which makes it a natural space for questioning certitude.

As a discourse-analyst faced with the recent discoveries in neurosciences around mirror neurons, I am well aware of the perilous nature of such positioning on the border between fiction and reality and clearly claim, in this enterprise, the status of a dilettante, or to borrow Siri Hustvedt's words, "an outsider, an unaffiliated intellectual roamer who follows her nose and has found herself on unexpected ground, surveying landscapes I knew very little about before I arrived on site"

This paper is thus a modest attempt at combining perspectives from various fields of research to try and gain new insights into the way we, as readers of fiction come to terms with radical otherness, be it the characters', the writer's, or our own, and the consequences it has on our understanding and deciphering of the world. I will therefore be "arguing at the cross-roads", freely connecting discourse analysis, philosophy and neuro-sciences, reality and fiction. With the firm conviction that "no single theoretical model can contain the complexities of human realities", we shall investigate how Bernard MacLaverty's "Father and Son" makes us literally experience otherness while William Trevor's "Lost Ground" traces a painful path to uncompromising awareness. Experience might eventually lead us, in Eòin Flannery's words, "to discern the stirrings of resolution or accommodation across antagonistic communities" in Colum McCann's

2. Anne Enright, The Granta Book of Irish Short Story, Grant, London, 2011, p. xv.

3. Ibid., p. x.

4. Siri Hustvedt, Living, Thinking, Looking, Picador, New York, 2012, p. XII.

5. As an echo to Paul Brennan and Catherine de Saint Phalle's title, Arguing at the Crossroads, Essays on a Changing Ireland, New Island Books, Dublin, 1997.

6. Hustvedt, op. cit, p. x.

7. Eòin Flannery, "Troubles' Trilogy: Everything in this Country Must, in Susan Cahill and Eòin Flannery (eds.), 
multidimensional triptych, Everything in this Country Must. "It becomes history by becoming fiction ${ }^{8 ”}$.

\section{Mirrors in our brain?}

In the preface to Narcissistic Narrative, the Metafictional Paradox, Linda Hutcheon recalls what she terms her "traumatic" meeting with Wolfgang Iser" in the 1970s, since it led to her rewriting the entire $\mathrm{PhD}$ dissertation she was just about to hand in: "How could I have thought I could theorize self-reflexive fiction without thinking of the reader - the workings of whose creative imaginative processes were being redefined by metafiction ${ }^{10}$ ?" How indeed? What was then considered a revolutionary stance in the study of literature is by now broadly taken for granted, even if vivid discussion still goes on about the importance of the reader's role in the construction of meaning and the degree of creativity they might be allowed in handling the questions of interpretation and intentionality. Yet, given what Iser described in his last book "the indeterminacy in a text ${ }^{11}$ ", any interpretative position is bound to be elusive: "But how shall we then describe the dynamic character of a text? Can one, in fact, assess the keen disturbance so often experienced in reading serious literature ${ }^{12}$ ?"

Today, in 2015, that crucial question might find different answers to those in 1989, thanks in particular to the development of neurosciences. In an interview recorded at the University of Parma in February 2011, Giacomo Rizzolatti, Professor of Human Physiology, traces the evolution in his research ${ }^{13}$. The initial step was their ground breaking discovery in the 1990s of mirror neurons in the cortical motor system of macaque monkeys: the same neurons fire when a monkey grasps a peanut as when it watches another monkey (or indeed a human) grasp another peanut ${ }^{14}$ ! Hence their name. The team then went on to evidence the pre-

This Side of Brightness. Essays on the Fiction of Colum McCann, Reimagining Ireland, Vol 17, Oxford, Peter Lang. 2012, p. 57-74.

8. Colum McCann, in "Joseph Lennon, 'The First Man to Whistle': Two Interviews with Colum McCann", in Cahill and Flannery (eds.), 2012, p. 154.

9. Co-founder, with Hans Robert Jauss of the Constance School, and famous developer of the reader-response theory.

10. Linda Hutcheon, Narcissistic Narrative, the Metafictional Paradox, Waterloo, Wilfrid Laurier University Press, (1980), 2013, p. XI.

11. Wolfgang Iser, Prospecting, From Reader Response to Literary Anthropology, Baltimore, Johns Hopkins University Press, 1989, p. 3.

12. Ibid., p. 5 - the emphasis is mine.

13. [http://www.gocognitive.net/interviews/giacomo-rizzolatti-mirror-neurons]. I choose to refer the reader to these interviews first which offer a very clear presentation of a very complex subject, even to non specialists of neurosciences (like myself). The reference book remains Giacomo Rizzolatti, Corrado Sinigaglia, Mirrors in the Brain: How Our Minds Share Actions, Emotions, and Experience, OUP, 2008.

14. [http://www.gocognitive.net/interviews/discovery-mirror-neurons-1]. 
sence of those mirror neurons in humans before addressing the question of emotions and discovering another "mirror mechanism embedded inside our emotional centres". In Rizzolatti's words, "this is extremely interesting because it is another way in which we communicate, given that communication is understanding the others from the inside ${ }^{15}$ ". The intimate intertwining of mind and body brought to light by the discovery of mirror neurons which, further research shows, are activated during execution, imitation or observation of actions ${ }^{16}$, emotions or sensations, or while listening to, or reading, words or sentences describing them, irretrievably undermines the frontier between self and other, between reality and imagination/fiction.

Experiencing, feeling the world around, in ourselves - in one word: "Einfühlung". Jacques Hochmann, in Une histoire de l'empathie, explains that the term was invented in 1873 by Robert Vischer, originally to translate an aesthetic experience of projection of the observer's mind into artistic objects. It was then taken up by Freud along with the term "Sichineinversetzen"(to put oneself into someone's place) to describe identification processes as means of understanding the other, including in a therapeutical context. Gradually the meaning of the term evolved to describe "a feeling of intentional continuity with the other ${ }^{17 \text { " and came }}$ to be translated as "empathy" in 1909 by Edward Titchener ${ }^{18}$. Thus, empathy takes us from subjectivity to intersubjectivity, before eventually coming to be seen as a way to discover aspects of ourselves that were previously unknown to $\mathrm{us}^{19}$. Besides, the very existence of Mirror Mechanisms tends to foreground a conception of empathy anchored in biology, thereby echoing the phenomenological conception of intersubjectivity as intercorporeity (as developed by Merleau-Ponty and Ricoeur in particular).

\section{圈 Experiencing otherness: "Father and Son", a puzzle of interlacing empathies}

Bernard MacLaverty's opening story of A Time to Dance, "Father and Son"20", as its title intimates, is about relation; it turns out to be about a keenly problema-

15. [http://www.gocognitive.net/interviews/emotional-mirror-mechanism].

16. and also when the action can only be predicted from clues, or can only be heard; see Gallese: "From Mirror Neurons to Embodied Simulation" part 1 video, 25'37". [http://www.youtube.com/watch? $v=P l V 7 F 3 M H u E k]$.

17. Jacques Hochmann, Une Histoire de l'Empathie, Paris, Odile Jacob, 2012, p. 47.

18. Ibid., p. 51.

19. Hochmann sums up the argument put forward by Husserl's assistant, Edith Stein, in her thesis about " Einfühlung" in the following way: "l'empathie non seulement me donne accès à l'autre mais, en me permettant de me retrouver dans sa personne et de découvrir "son unité de sens", me procure un contact plus profond avec moi-même " ( Ibid., p. 78).

20. Bernard MacLaverty, A Time to Dance, London, Penguin Books, 1982, p. 9-14. All page references are to this edition. 
tic father-son relationship, presented to us in a keenly disturbing way, alternating three perspectives and three narrative voices to give the reader a nuanced threedimensional picture of a complex reality.

The title initially defines a double object of focus, leading us to expect an external, high-angle perspective. Yet, the first disruption occurs with the first paragraph:

Because I do not sleep well I hear my father rising to go to work. I know that in a few minutes he will come in to look at me sleeping. He will want to check that I came home last night. He will stand in his bare feet, his shoes and socks in his hand, looking at me. I will sleep for him. Downstairs I hear the snap of the switch on the kettle. I hear him not eating anything, going about the kitchen with a stomach full of wind. He will come again to look at me before he goes out to his work. He will want a conversation. He climbs the stairs and stands breathing through his nose with a empty lunch box in the crook of his arm, looking at me. (9)

Perspective and voice are subjective; they are those of the son, the first homodiegetic narrator we encounter, the first one we empathize with. His main object of observation is his father, but, tracing Mirror Mechanisms (MM), "rising to go to work" is an action mentally shared by the son inside the story because he hears it, and by us, because we are reading about it. The son can therefore be described as empathizing with his father, and the reader empathizing both directly with the father and with the son empathizing with his father. The same embedding seems to occur with "he will come in to look at me sleeping" although the interpretative dimension complexifies the empathy process. "[T]o look at me" expresses an intention, just as "he will want to check" and thus can also be seen as instances of Theory of Mind, defined as the capacity to perceive and interpret the other's intentionality. The son claims to be familiar with his father's intentions; because of MM the reader probably first shares this claim, but it being an interpretation on the son's part, there remains the possibility that we might withdraw. The situation is further complicated by the fact that the object of observation doubles up on itself; the father is perceived by his son, but the son also perceives himself as his father sees him. The entanglement of the relationship reaches a climax in this opening paragraph with the rather disturbing sentence: "I will sleep for him". Why "sleep for"? Does it simply mean: he will think that I am asleep, the son merely putting himself in his father's shoes? Does the son intend to match his behaviour with his father's expectation as he himself perceives it? Or does he clearly intend to manifest a refusal to communicate with his father? The focusing on his father's gestures and the precision of the deciphering: "I hear him not eating anything", the attribution of intention: "He will want a conversation" that 
follows, tend to prevent any stable interpretation. The son's relation to his father is clearly ambivalent. Empathy with the son is problematic for the reader.

Interestingly enough, this is not the case as far as empathy with the father is concerned; the closing description of the father seems unproblematic in terms of $\mathrm{MM}$ and our corresponding mirror neurons fire as we read "he climbs the stairs and stands breathing through his nose [...] looking at me". As Guillemette Bolens explains:

En utilisant l'imagerie fonctionnelle à résonnance magnétique, Olaf Hauk, Ingrid Johnsrude et Friedemann Pulvermüller ont montré que le cortex moteur et prémoteur est activé à la lecture silencieuse de verbes d'action. La lecture silencieuse de verbes associés respectivement à l'action du pied, de la main ou du visage tels kick [...], pick [...] et lick [...] active de façon différentielle les zones cérébrales associées aux mouvements effectifs du pied, des doigts ou de la langue ${ }^{21}$.

This seems to prove that MM work on a double level; they are involved on a first, biological level but also on a more complex cognitive level where they combine with ToM. What the reader cannot fail by now to see as a problematic relationship, the text makes him literally experience, feel, articulating and actualizing what is more traditionally known as mimesis.

The second paragraph of the story contrastively presents the reader with another homodiegetic perspective and voice, that of the father:

This is my son who let me down. I love him so much it hurts but he won't talk to me. He tells me nothing. I hear him groan and see his eyes flicker open. When he sees me he turns away, a heave of bedclothes in his wake. (9)

Empathy mechanisms are very similar to those in the opening paragraph; as readers, we empathize with the father, a father who empathizes with his son and deciphers his behaviour very clearly, a fact we can appreciate, given our previous experience of the son's meandering mind. The father's perspective is simpler here than that of the son, more descriptive; consequently the reader's experience is more direct. We can feel the pain, and this again is meant literally. There is no attempt at explaining the son's behaviour; the father does not offer interpretations nor does he try to picture himself as his son sees him. The connection between father and son is also established by mirroring patterns on the stylistic level: "I hear him not eating anything" finds an echo in "He tells me nothing"; "will" becomes "won't"; hearing and seeing are in both perspectives acute modes

21. Guillemette Bolens, Le style des gestes. Corporéité et kinésie dans le récit littéraire, Lausanne, BHMS, 2008, p. 9. 
of apprehending the other's world. The two characters therefore appear as two mighty opposites, and as readers, it is our priviledged experience to empathize directly with both. The third paragraph widens the picture:

Wake up, son. I'm away to my work. Where are you going today?

What's it to you?

If I know what you're doing I don't worry as much.

Shit. (9)

The use of Free Direct Style - which entails the disappearance of the narrative voice - leaves the reader on his own in the fictional world; yet, by now, we have most probably completely integrated it. Green and Carpenter offer the term "Narrative Transportation" to refer to this "state of cognitive, emotional and mental imagery engagement in a story ${ }^{22}$." We can therefore be said to "overhear" a conversation which displays a complete breach, on the son's part, of the most elementary conversational rules, and first among them, of Geoff Leech's Politeness Principle ${ }^{23}$ (all six maxims are breached; there is no Tact nor Generosity, no Approbation nor Modesty, no Agreement nor Sympathy in the son's words!). This would tend to bar empathy for the son; and yet, because of the father's maintaining the link through dialogue, and because of our empathizing with the father, the connection with the son is nevertheless preserved. The impact of this sharp exchange is essentially to make it possible for us to start finding our way out of the empathic maze of the first paragraph, without telling us what to think. In Merleau-Ponty's words:

Le romancier n'a pas pour rôle d'exposer des idées ou même d'analyser des caractères, mais de présenter un événement interhumain, de le faire mûrir et éclater sans commentaire idéologique ${ }^{24}$.

The narration goes on along the same lines, interlacing the three perspectives that have been isolated here, leading the reader to empathize with both characters at the same time, to feel their distress, to share the father's desire for relation, the son's simultaneous longing for ${ }^{25}$, and refusal of, interaction, and above all, leading us not to choose between the father or the son.

At the final point:

22. M. Green and J. Carpenter, "Transporting into Narrative Worlds ", Scientific Study of Literature, I:1, 2011, John Benjamins Publishing Company, p. 115.

23. G. Leech, Principles of Pragmatics, Longman, London, 1983, p. 104-151.

24. M. Merleau-Ponty, Phénoménologie de la perception, Paris, Gallimard, 1945, p. 177. My emphasis.

25. Apart from MM and embedded empathy, the main technique used to point to this longing for interaction on the son's part is the emerging of the "you" as addressee of the son's monologue: "Your hand shakes in the morning, Da, because you're a coward. You think the world is waiting round the corner to blow your head off." (p. 11). 
There is a bang. A dish-cloth drops from my hand and I run to the kitchen door. Not believing. I look into the hallway. There is a strange smell. My son is lying on the floor, his head on the bottom stair, his feet on the threshold. The news has come to my door. The house is open to the night. There is no one else. I go to him with damp hands.

Are you hurt?

Blood is spilling from his nose.

They have punched you and you are not badly hurt. Your nose is bleeding. Something cold at the back of you neck.

I take my son's limp head in my hands and see a hole in his nose that should not be there. At the base of his nostril.

My son, let me put my arms around you. (14)

The reader is left alone with the father; we hear the bang, run to the kitchen door, look into the hallway, smell the strange smell, picture the scene, go to the son, take his hand, see the hole in his nose and eventually put our arms around him. The emotion we feel at the end of this story, an e-motion (from the Latin exmovere) that shifts our centre of gravity, is clearly the immediate result of Mirror Mechanisms.

Indeed further research around mirror neurons makes it possible to connect the initial levels of action and emotion with what happens when we read a text. In "How Stories Make Us Feel: Toward an Embodied Narratology"26", Hannah Wojciehowski (Associate Professor of English at the University of Texas) and Vittorio Gallese (Professor of Physiology in the University of Parma Department of Neuroscience) set out from their different backgrounds to trace "one important level of our relationships with narrative - namely, our empathic co-feeling with others activated by writings and registered within our bodies". The study, they claim, takes us beyond intentionality and what is traditionally known as Theory of Mind (ToM) to what they call Feeling of Body (FoB):

FoB is the outcome of a basic functional mechanism instantiated by our brain-body system, Embodied Simulation, enabling a more direct and less cognitively-mediated access to the world of others. [...] According to this hypothesis, intersubjectivity should be viewed first and foremost as intercorporeity ${ }^{27}$.

26. Hannah Wojciehowski and Vittorio Gallese, «How Stories Make us Feel : Toward an Embodied Narratololy, University of California, California Italian Studies, 2(1), 2011. [http://escholarship.org/uc/item/3jg726c2]. Unfortunately, there are no page indications in the internet version of this article and the references of the quotations cannot be more precise. Emphasis is mine.

27. Which takes us back to the phenomenologist conception of relation. 
Besides, scientific experiments show that there is not much difference in the neurons that fire when we are watching someone perform an act or when we are imagining $\mathrm{it}^{28}$, or indeed when we are reading about it:

The aesthetic experience of art works, more than a suspension of disbelief, can be thus interpreted as a sort of 'liberated embodied simulation'. [...] Through an immersive state in which our attention is focused on the narrated virtual world, we can fully deploy our simulative resources, letting our defensive guard against daily reality slip for a while ${ }^{29}$.

A common, "we-centric space" is thus created, in which we find ourselves included, at the father's side, next to his son.

Yet, according to Wojciehowski and Gallese, the same mechanism also applies to the author: "Liberated embodied simulation hence provides a potentially unified level of description of both author's and reader's relation with the text". This may thus eventually lead to what they call "Embodied Narratology" which, "when combined with the evidence on the we-centric, pre-individual space instantiated by the shared resonance mechanisms we have reviewed above can perhaps enable a naturalized version of humanism - a neuro-humanism $[\ldots]^{30}$ ". Mirror Mechanisms, often combined with ToM, are therefore also present at the author (and/or heterodiegetic narrator) - reader more complex level of interaction, and secure their tight relationship; we are not allowed to escape the deep irony of the ending. Interestingly here, irony is also based on echoing and textual mirroring mechanisms. Thus, "The news has come to my door" echoes a preceding passage where reality and imagination clash:

I have not seen my son for two days. Then, on the radio, I hear he is dead. They give out his description. I drink milk. I cry.

But he comes in for his tea. (11)

Death had not come when the father thought it had, but it eventually will in a moment of misinterpretation:

It is ten o'clock. The news begins. Like a woman I stand drying a plate, watching the headlines. There is a ring at the door. The boy answers it, his shirt tail out. Voices in the hallway.

My son with friends. Talking. What he does not do with me. (14)

28. In another study, "Seeing art... beyond vision. Liberated embodied simulation in aesthetic experience", [http:// www.unipr.itlarpa/mirror/pubs/pdffles/Gallese/2011/guggenheim_2011.pdf, Gallese explains that "Brain imaging studies demonstrate that when we imagine a visual scene, we activate the same visual regions of our brain normally active when we actually perceive the same visual scene".

29. Wojciehowski and Gallese, 2011.

30. Ibid. 
There are many other motifs in the text, beside the motif of the news, that are ironically mirrored and displaced and which readers have to connect, recalling the medieval technique of interlacing to be found in Celtic manuscripts like the Book of Kells ${ }^{31}$. The fishing motif is recurrent; it occurs as a happy memory for the father: "When he was a boy I took him fishing"(10), for the boy: "He used to fish. To take me fishing."(12), before the motif is taken up by the heterodiegetic voice in a distorted, ironical perspective: "The boy curls his lip as if snagged on a fish-hook" (12). If one further considers that the fish, in Celtic mythology, is the symbol of knowledge, the resonance is sinister. The quest for knowledge, intimated by the opening word of the story, "Because", is indeed doomed. The arm around the shoulder is another key image. The only moment when this much longed-for gesture will be made possible is when the son is dead, striking yet another bitter ironical note at the end.

The reading experience is deeply disturbing, and an urgent question inevitably raised: what is the point?

\section{圈 “The end of art is peace ${ }^{32 "}$}

Between a "you" and a "I", the empathic process opens an intermediary space, similar to Donald W. Winnicott's "transitional space", a space to play in, a space of imagining, a space of experiencing, which is both immediately intradiegetic and complexly extradiegetic, as our close reading of MacLaverty's story has shown. Ultimately, empathy must therefore be seen as an intrinsically metaleptic process, a perpetual stepping over the threshold between the diegetic world and the extradiegetic level of "reality". Gérard Genette in Metalepsis describes the process:

Cette transfusion perpétuelle et réciproque de la diégèse réelle à la diégèse fictionnelle et d'une fiction à une autre, est l'âme même de la fiction en général et de toute fiction en particulier. Toute fiction est tissée de métalepses. Et toute réalité, quand elle se reconnaît dans une fiction et quand elle reconnaît une fiction en son propre univers ${ }^{33}$.

Metalepsis can in many ways appear transgressive, since fiction and reality are generally considered as ontologically heterogeneous; yet, the division theorized by text-world analysis and which generally goes unquestioned between "discourse

31. "La répétition des signifiants et de leurs synonymes dessine des lignes qui s'entrecroisent pour ensuite disparaître et refaire surface plus loin, semblables aux entrelacs picturaux des enluminures médiévales[...] Lire un entrelacs consiste à porter attention à des signifiants dont la réitération indique qu'ils jouent un rôle distinctif dans la construction de la narration.» Guillemette Bolens, Le style des gestes. Corporéité et kinésie dans le récit littéraire, Lausanne, BHMS, 2008, p. 36-37.

32. Seamus Heaney, "The Harvest Bow", Field Work, 1979.

33. Gérard Genette, Métalepse, Paris, Seuil, 2004, p. 131. 
universe" (the universe of readers and authors, or in Genettian terms the "extradiegetic" level) and "text worlds" (the worlds of characters, or the "intradiegetic" level) is increasingly problematic; it leaves unsolved the question of the positioning of the heterodiegetic narrator who stricto sensu belongs to neither space. It also leaves unanswered the widely shared experience of readers, and indeed authors, feeling themselves involved in the text world, alongside the fictional characters. "Sometimes I want to run away and just spend an afternoon in the pub with my characters", McCann confesses ${ }^{34}$. Experience seems to question narrative theory here and call for a radical renewal of perspective that would eventually make it possible to include fiction and reality in a shared ontological space. This is generally considered anathema, but it seems to be the only way to account for the complexity of the relation to the Other in fictional writing. Mirror Mechanisms might help us operate such a shift.

Hochmann explains: "Le processus empathique [...] nécessite à la fois le maintien d'une visée égocentrée (le sentiment d'identité) et le dédoublement de soi vers l'autre, le passage à une perspective allocentrée, avec une prise en compte des intentions d'autrui $i^{35}$." This movement towards otherness is, according to Ricoeur, a question of ethics : "la position d'autrui en tant qu'autrui - la reconnaissance d'une pluralité et d'une altérité mutuelle - ne peut pas ne pas être éthique ${ }^{36 "}$. Empathic reading, in the light of Irish experience, therefore takes on new meaning.

"Father and Son" was first published in 1978. The period was that of "The Troubles" and Bernard MacLaverty, born in 1942 in Northern Ireland, "that cauldron of sectarian stuff ${ }^{77}$, had moved to Scotland in 1975:

In a way you write from anger. In the first novel [Lamb], the anger is against what the institutionalised church does to people, so that you end up with tragedy. The anger in the second novel [Cal] comes from violence. They're spurs to your creativity, because as an individual you can't do anything to stop violence. You can try and write something ${ }^{38}$.

Conflicts, which generally arise from a total inability to take into account the perspective of the other, led many Irish writers to exile. James Joyce, John McGahern were forced to leave because they expressed a difference that was unacceptable to censors. William Trevor, born in 1928 in Southern Ireland in a Protestant family, moved to England in the 1950s, first for economic reasons, but it turned

34. "Joseph Lennon, 'The First Man to Whistle': Two Interviews with Colum McCann", p. 165, in Cahill and Flannery (eds.), 2012, p. 149-175.

35. Ibid., p. 168.

36. Ricœur, quoted in Hochmann, 2012, p. 90.

37. An Interview With Bernard MacLaverty, by D. R.Fernandes, Barcelona Review, Nov-Dec 2006, [http://www. barcelonareview.com/56/e_int.htm].

38. Ibid. 
out that leaving Ireland was essential to his evolution as a writer: "Most writers benefit from exile [...] Being a Protestant in Ireland [...] began the process of being an outsider - which I think all writers have to be ${ }^{39}$." Closer to us Colum McCann, born in Dublin in 1964, moved to New York:

New York is the city of exiles - everyone comes from somewhere else. Ireland has been for years a country of exiles - everyone wanting to be somewhere else.

The Irish writer has always had a peculiar home in the world. By a combination of strategies — going into exile, subverting the language, twisting the fictional form - he or she has, in general, remained provocative, at the edge ${ }^{40}$.

Three generations of writers, living elsewhere, and yet strongly emphasizing their Irishness and their involvement with history, interrogating their power as authors. MacLaverty is talking about anger, McCann about rage:

There's too much power in language. I believe we must have a rage and a belief that it does matter. [...] Put it like this: when the North of Ireland was being torn apart, limb by fucking limb, there were books being bought in the North, there were poems being written (Heaney, Longley, Carson, Muldoon were all writing political poems).

I don't know if those poems went on to heal any of the wounds, but I have to believe that they helped, that the fact of their existence was a stay, even if an unrecognized one, against insanity. I advocate poets as Presidents but it'd be ridiculous - to be a poet you must engage in contradiction.

[...] Spending summers in Northern Ireland - hearing about my cousins being hauled off and strip-searched by British squadies at the side of country roads - was an experience that outraged me, politicised me, though I didn't say anything about it for many years ${ }^{41}$.

In this conversation with Sarajevo-born writer Sasha Hemon, McCann goes on asking about "the question of whether we write our own history, or whether history writes our story for us", while MacLaverty asserted in the Barcelona Review interview "I think the very act of writing itself is political".

If Ireland's history is clearly one of conflict - conflict with radical otherness, the British enemy from without, the conflicting points of view that make the

39. William Trevor, The Art of Fiction No. 108, Interviewed by Mira Stout, Paris Review, [http://www.theparisreview.org/interviews/2442/the-art-of-fiction-no-108-william-trevor].

40. Colum McCann, Zoli Interview, Q\&A with Michael Hayes, [http://colummccann.com/interviews/].

41. Conversation with Sasha Hemon, [http://colummccann.com/interviews/]. 
weave of the most disturbing stories concern the impact of external conflict on the private sphere; conflicts of allegiance in families or in the self and the sharp experience of inescapable clear-sightedness.

\section{When "know" becomes an intransitive verb}

Although Trevor is less explicit about political involvement than MacLaverty or McCann, many of his stories use the combination of a heterodiegetic narrator and multiple internal perspectives to make the reader experience the devastating consequences of sectarianism and bigotry on the characters' intimate lives. Originally published in 1992, "Lost Ground ${ }^{42}$ ", set in County Armagh, tells the story of a young Protestant boy. In his father's apple orchard, the aptly named Milton encounters a mysterious woman who introduces herself as "St Rosa"! In his quest for information, getting no answer from his brother-in-law, a Protestant minister, other than "if you ignored what happened, it wouldn't be there anymore" (119), he commits the highly subversive act of going to see the Catholic priest of the town, with equally little result; he then feels an uncontrollable urge to go out preaching and telling about his mystical experience. Annoyed by what they consider unacceptably disruptive behaviour, his family eventually decide to keep him locked up in his room, where he finally spends his time completing jigsaw puzzles while trying to make sense out of his predicament and his family's reaction. The text itself becomes a vast jigsaw puzzle; the combination of heterodiegetic narration and MM makes us follow different perspectives that dovetail with one another; that of Milton, who can be considered as the main reflector of the story, but also that of the different family members, and especially that of one of his sisters, Hazel, who left Ireland, presumably for good, when she married. On the Orange Parade Day, Milton is mysteriously murdered, and Hazel is back for the burial.

In a clear epiphanic passage, in the graveyard, we are suddenly "transported" into her perspective: "Garfield stood a little away from them, with a black tie in place and his shoes, black also, not the trainers he normally wore. Looking at him across the open grave, Hazel suddenly knew" (131). No need for a complement here; ellipsis creates intransitivity that makes knowledge absolute and radical. This is the surprisingly simple result of Mirror Mechanisms; Hazel looks at Garfield, their brother, officially a butcher's assistant in Belfast, and so do we; in the process her understanding becomes ours. Her understanding too that everybody "knew": "All of them knew, Hazel's thought ran on: her father knew, and her mother, and

42. William Trevor, Selected stories, Penguin Books, London, 2009, p. 107-132. All page references are to this edition. 
Addy, and Herbert Cutcheon. It was known in every house in the neighbourhood; it was known in certain Belfast bars and clubs, where Garfield's hard man reputation had been threatened, and then enhanced" (132). The epiphany eventually erases all difference whatsoever between characters and readers and the final choice of the passive form turns all of us into silent accomplices.

The end of the story is scathingly ironical, still seen through Hazel's eyes, transmitted in a narrative that slips into Free Indirect Style, an intrinsically polyphonic mode: "The family would not ever talk about the day, but through their pain they would tell themselves that Milton's death was the way things were, the way things had to be: that was their single consolation. Lost ground had been regained' (p. 132, emphasis mine). Empathy mechanisms, anchored in the character and the narrator, but also in the author, through the echo with the title, unambiguously, because of its paratextual position, attributable to Trevor, lead the reader to perceive the ironical undermining of the final assertion. With death, lost ground cannot ever be regained. The only clear-sighted perspective is that of the voluntary outsider, the third party. Ironical inversion and echoing inevitably initiate a reflection on the nature of, and relation to, that "lost ground". In the context of Irish History, where so much is a question of space, ground lost and (re)gained, Trevor's very act of implicit questioning signs a political stance that we cannot escape.

\section{橉 "I like to think that stories can get to the pulse of the wound"}

Ellipsis, silence and obliqueness are Trevor's privileged instruments of political awareness. In MacLaverty's "Father and Son", intertwined opposite perspectives forcing the reader to empathize with both sides simultaneously weave the political dimension of the writing act. Everything in this Country Must combines all strategies. The stories are about adolescence in times of "Troubles", and as Eòin Flannery insists in his study of the trilogy, "the body' [is] a recurrent thematic presence [...] exhibited as a site of political and cultural contestation and as a resource for possible political solidarity in the Northern Irish context ${ }^{44}$ ". This biological anchoring logically foregrounds the potential importance of mirror mechanisms in the reading experience, reminding us that "biology" is indeed another language, bio-logos, the language of life.

The opening story, "Everything in this Country Must", follows the perspective of the autodiegetic narrator, a young Catholic girl, Katie, torn between her alle-

43. Joseph Lennon, “The First Man to Whistle': Two Interviews with Colum McCann”, p. 157, in Cahill and Flannery (eds.), 2012, p. 149-175.

44. Eòin Flannery, “'Troubles' Trilogy: Everything in This Country Must", in Cahill and Flannery (eds.), 2012, p. 58. 
giance to her father and her burgeoning love for Stevie, one of the young British soldiers who helps them rescue their draught horse which was drowning. At the end of the story, the father, in an unbearable act which the reader is nevertheless led to understand through direct and embedded Mirror Mechanisms, shoots the horse:

When Father came in from outside I knew what it was. His face was like it was cut from stone and he was not crying anymore and he didn't even look at me, just went to sit in the chair. He picked up his teacup and it rattled on the saucer so he put it down again and he put his face in his hands and stayed like that. The ticking was gone from my mind and all was quiet everywhere in the world and I held the curtain like I held the sound of the bullet going into the draft horse, his favourite, in the barn, one two three, and I stood at the window in Stevie's jacket and looked and waited and still the rain kept coming down outside one two three and I was thinking oh what a small sky for so much rain ${ }^{45}$. (15)

The story's power relies, as often, on ellipsis; the issue is to make us feel the unspeakable. Everything in this country must... die. Death is everywhere and it remains in suspension, waiting for an evaluative resolution it will never be given; the mother and brother die after being hit by a British army truck and "the judge said Nobody's guilty it's just a tragedy" (9). We therefore understand why the father kills the horse, we feel his distress, though the act cannot have any acceptable justification. The daughter's perspective and voice, characterized by her difficulty to connect events logically - stylistically engrained in the unusual scarcity of punctuation and her almost exclusive use of "and" as a link word - create a feeling of strange disturbance in the reader whose mind responds to the father's and the daughter's gestures. Trauma seems to leave scars that we can only be made to feel ; in Vladimir Jankelevitch's words, "est indicible, à cet égard, ce dont il n'y a absolument rien à dire, et qui rend l'homme muet accablant sa raison et médusant son discours $^{46}$ ". It is the privilege of Mirror Mechanisms to take us as far as that sideration of body and mind.

Death and allegiance are also at the heart of the second story, "Wood", another autodiegetic narrative which works as counterpoint to the first. We here follow the perspective of a young Protestant boy, Andrew, whose mother decides, unbeknownst to her husband, to accept an order for poles for an Orange March. It is winter, there is snow on the ground, and they work at the mill at night to

45. Colum McCann, Everything in this Country Must, Phoenix, London, 2000. All page references are to this edition.

46. Cité dans Catherine Mari, "Tell-tale ellipsis in Colum McCann's Everything in This Country Must ", JSSE, 40, Spring 2003, [http://jsse.revues.org/287]. 
have the poles ready. The atmosphere is eerie; the mother drives the tractor, guides the saw, plays a man's role; her son admires her while tenderly recalling his father's presence before a stroke left him paralysed. The conflicts in perspectives here are less devastating and violent than in the previous story. The father's remark about the marches, remembered by his young son and integrated in his narrative discourse through the use of Free Direct Style, a privileged stylistic marker of MM, reveals critical distance on sectarianism: "Daddy says he's as good a Presbyterian as the next, always has been and always will, but it's just meanness that celebrates other people dying" (22). It interlaces with the mother's decision to overlook her husband's position. But the issue is that she/ they simply need the money. The political recedes behind the economic. Again, as readers, espousing gestures and decisions, we intimately feel the conflict in allegiance, without judging it.

The last story, "Hunger Strike" is set in County Galway; although the narrator here is heterodiegetic, the point of view is internal; Free Direct and Free Indirect Styles are dominant. It opens on a young boy - the reflector ${ }^{47}-$ observing an old couple rowing on a yellow kayak. We understand that the mother took her fatherless son away from Northern Ireland (Derry), where her brother, a young IRA prisoner on a hunger strike, is dying. The young boy, although he has never met him, decides to experience in his own body his uncle's predicament and refuses food, which could diegetically be analyzed as the acting out of MM (with no inhibition of action) and which is stylistically expressed through the sporadic emerging of a confusing spatio-temporal frame common to the young boy and his uncle:

In the caravan they spread out the Sunday papers on the table. There were photographs of his uncle from years ago. He ran his fingers over the face, then cut the pictures out very carefully, put one in his shirt pocket, taped the other above his bed. Later, as he played chess with his mother, using the wooden pieces, he patted the photo in his pocket and it felt as if his fingers were moving over his uncle's ribs. They felt prominent, like the ribs of a hungry horse. The bones made a sound like some musical instrument and, when he shoved his fingers deeper into the pocket, he could feel the water swish in his uncle's belly. (113, emphasis mine)

Sensations transcend time and place for character and reader alike and the story is repeatedly interrupted by weight notations and comments. Parallel to that thread runs the development of the friendship between the elderly Lithuanian couple observed at the beginning and the young boy whom the man teaches to row; the combination creates tension in the working of MM: "Each day they

47. A meaningful term in the context of MM. 
went out in the boat as his uncle weakened further" (108). The ending culminates in a puzzling, mis-targeted, gratuitous form of violence we are nevertheless led to understand in our minds since we have experienced the uneasiness all along in our bodies. Upon guessing about his uncle's death, the young boy stones the elderly couple's kayak. The closure of the text, through what is by now a familiar process, suspends evaluation; we feel "the pulse of the wound", standing next to the boy, in his confused spatio-temporal frame and next to the couple, sharing, through MM, actions, sensations and emotions:

Combing the beach again, he found even larger rocks. His whole body was trembling now. He was on the street. He was at a funeral. He had a bottle of fire in his hands. He was in a prison cell. He pushed a plate away from his bedside.

It was only with the twelfth rock and another long ringing of the phone that he saw at last the spidery splint of fibreglass.

$[\ldots]$

When his sobs subsided the boy lifted his head from the boat, looked back over his shoulder, saw the light from the house of the Lithuanians, the front door open, the couple standing together, hands clasped, watching, the old man's eyes squinting the old woman's large and tender. (143)

Tenderness is literally given the last word in a volume which moves towards catharsis and resilience, and this too can be interpreted as a political act. As Eòin Flannery concludes in his enlightening study of Everything in this Country Must:

We can view McCann's collection as a literary response to, indeed valediction of, the various tentative steps toward cross-factional accord that took public, material form in the mid to late 1990s. The emergent bodies and minds defy, or are encouraged to defy, the artificial political and cultural tenets of sectarianism ${ }^{48}$.

\section{Work in progress...}

As readers, we have been led into disturbing stories of conflict, intimate perspectives on allegiance that call for a radical questioning of certitude. On a first, immediate, biological and therefore hardly escapable level, Mirror Mechanisms lead us to experience in ourselves (bodies and minds) what we are reading about in the text, no matter how alien to us or how contradictory it might feel. This

48. Eòin Flannery, 2012, p. 74. 
rather simple, quasi automatic neuronal procedure often creates a strong impression of unbalance and puzzlement which is not without connection with de-familiarization processes. Empathy, via more complex mirror neuron networks often involving embedding and foregrounding, can then be analyzed as a privileged strategy to "transport" us into alien territory, to force us into a detour through other minds to espouse radically other perspectives. The consequence is often shock, puzzlement, and in all cases suspension, deferring, of evaluation, eventually hopefully resulting in a change of perspective, on the others, but also possibly on ourselves. We are transformed by our reading, we become Sceptics, setting aside judgements learned through our culture and taken for granted, and this is indeed a political act and strategy:

I want to create texts that break through the policing of our borders[.... Well, I think a reader should become a writer at the end of the novel. The novel should be left open for interpretation. [...] I want the reader to have the dignity of his or her own interpretation of the text. I don't want to tell people how to think. I'll leave that up to others ${ }^{49}$.

This "creative reading" Colum McCann repeatedly insists on is originally grounded in Mirror Mechanisms and embodied simulation, as Gallese and Freedberg explain:

Several studies show that motor simulation can be induced in the brain when what is observed is the static graphic artefact that is produced by the action, such as a letter or a stroke [...] using fMRI, Longcamp et al showed that the visual presentation of letters activated a sector of the left premotor cortex that was also activated when participants wrote the letters ${ }^{50}$.

V. S. Ramachandran, the author of The Tell-Tale Brain ${ }^{51}$, was probably right when he said in 2000: "I predict that mirror neurons will do for psychology what DNA did for biology: they will provide a unifying framework and help explain a host of mental abilities that have hitherto remained mysterious and inaccessible to experiments ${ }^{52}$." What they certainly do is give a scientific anchoring to what was hitherto

49. Colum McCann, Zoli Interview, Q\&A with Michael Hayes, [http://colummccann.com/interviews/].

50. David Freedberg and Vittorio Gallese, "Motion, emotion and empathy in esthetic experience", Trends in Cognitive Sciences, Vol $11 \mathrm{~N}^{\circ} 5$, Elsevier Ltd, 2007, p. 202. [http://www.italianacademy.columbia.edulart_and_ neuro/paper_sp07_FreedbergGallese.pdf], emphasis mine.

51. V. S. Ramachandran, The Tell-Tale Brain, Windmill Books, London, 2012.

52. V.S. bRamachandran, "Mirror Neurons and imitation learning as the driving force behind the great leap forward' in human evolution", Edge, 5/31/2000. Emphasis mine. [http://edge.org/3rd_culture/ramachandran/ ramachandran_pl.html]. 
an intuitive mode of apprehension of our relation to fiction. And, in some ways, it makes all the difference.

To Colum McCann, literature is empowerment; literature is reality. The creation of Narrative 4 proves it is not just an abstract idea:

some of the world's most renowned and influential authors, artists and community leaders[...] have come together to promote empathy through the exchange of stories. In an effort to break down barriers and shatter stereotypes, N4 encourages people to walk in each other's shoes and prove that not only does every story matter, every life matters ${ }^{53}$.

The project might look utopian, yet scientists once more, if allowed to have their say, can prove writers right. Recent experiments conducted by David C. Kidd and Emanuele Castano, from the New School for Social Research in New York, have shown that indeed reading literary fiction improves the capacity for Theory of Mind (ToM), and thus for empathy:

Just as in real life, the worlds of literary fiction are replete with complicated individuals whose inner lives are rarely easily discerned but warrant exploration. [...] Readers of literary fiction must draw on more flexible interpretative resources to infer the feelings and thoughts of characters. That is they must engage ToM processes. [...] Literature has been deployed in programs intended to promote social welfare, such as those intended to promote empathy among doctors and life skills among prisoners. [...] These results show that reading literary fiction may hone adults' ToM, a complex and critical social capacity ${ }^{54}$.

To careful readers of "literary fiction", this indeed does make sense and we might say we always knew it. ${ }^{55}$ But it is ultimately the ground-breaking idea of a mirror-neuron network underlying theory of $\operatorname{mind}^{56}$ that should lead to a renewed perspective on the study of fiction, provided we are ready to accept the challenge to our own theoretical positions. This will enable us to weave together into one harvest bow the findings of science, bio-logos, and literature, the experience of characters and readers, the skills of readers and writers, and give poetry power:

\section{3. [http://narrative4.com/].}

54. David C. Kidd and Emanuele Castano, "Reading Literary Fiction improves Theory of Mind ", Science mag. org, 3 Oct 2013 retrieved from [http://www.researchgate.net/publication/257349728_Reading_Literary_Fiction_Improves_Theory_of_Mind].

55. V.S. Ramachandran has this joke about what happens when a new discovery is made; the first reaction is "it cannot possibly be true!"; the second : "well it is true but doesn't explain anything!" and the third : "well it explains it, but anyway, we always knew it...!"

56. See V.S.Ramachandran, op. cit., 2012, p. 143-145. 
As you plaited the harvest bow

You implicated the mellowed silence in you

In wheat that does not rust

But brightens as it tightens twist by twist

Into a knowable corona

A throwaway love-knot of straw.

[...]

I tell and finger it like braille,

Gleaning the unsaid off the palpable ${ }^{57}$. 